\title{
ANALISIS KESALAHAN SISWA SD DALAM MENYELESAIKAN SOAL CERITA OPERASI HITUNG BILANGAN CACAH BERDASARKAN PROSEDUR NEWMAN
}

\author{
Patrisius Afrisno Udil ${ }^{1 *}$, Maria Elfantiana Senia ${ }^{2}$, Yosefina Lasam ${ }^{3}$ \\ ${ }^{1,2}$ Prodi Pendidikan Matematika, Fakultas Keguruan dan Ilmu Pendidikan, Universitas Nusa Cendana \\ ${ }^{3}$ Prodi Pendidikan Bahasa Inggris, Fakultas Keguruan dan Ilmu Pendidikan, Universitas Nusa Cendana \\ Jalan Adisucipto Penfui, Kupang, NTT, Indonesia \\ e-mail: ${ }^{1}$ afrisno.udil@staf.undana.ac.id \\ Submitted: August 3,2021 \\ Revised: September 8, 2021 \\ Accepted: September 13, 2021 \\ corresponding author*
}

\begin{abstract}
Abstrak
Penelitian ini bertujuan untuk menganalisis kesalahan dalam menyelesaikan soal cerita operasi hitung bilangan cacah pada siswa kelas II SD GMIT Oenesu, Kabupaten Kupang, NTT. Metode penelitian yang digunakan adalah deskriptif kualitatif yaitu dengan mendeskripsikan jawaban tes tertulis dan wawancara siswa berdasarkan kriteria kesalahan menurut Newman. Subjek dalam penelitian ini adalah siswa kelas II SD GMIT Oenesu, Kabupaten Kupang, NTT yang berjumlah 11 orang dengan subjek yang diwawancarai sebanyak 4 orang. Pemilihan 4 subjek dilakukan dengan teknik purposive sampling yaitu dengan memilih subjek atas dasar pertimbangan siswa sudah mendapatkan materi, adanya kesalahan yang dilakukan, dan siswa mampu mengkomunikasikan hasil kerjanya. Instrumen yang digunakan berupa tes tertulis dan pedoman wawancara yang telah divalidasi. Hasil penelitian ini menemukan bahwa 10 dari 11 siswa melakukan kesalahan dalam menyelesaikan soal cerita operasi hitung bilangan cacah, minimal pada salah satu soal tes. Selain itu, hasil penelitian ini juga menunjukkan bahwa kesalahan yang dilakukan siswa terkait dengan (1) kesalahan memahami masalah yaitu siswa tidak mampu mengidentifikasi informasi yang diketahui dan ditanyakan, (2) kesalahan mentransformasi masalah yang ditandai dengan kesalahan siswa dalam menuliskan representasi simbolik matematika dari cerita yang diberikan, (3) kesalahan keterampilan proses yaitu siswa tidak mampu menyelesaikan soal yang diberikan dengan prosedur penyelesaian yang benar, dan (4) kesalahan dalam menulis jawaban akhir yaitu siswa tidak menuliskan secara tepat simpulan akhir dari masalah yang diberikan. Lebih lanjut, kesalahan memahami dan mentransformasi masalah merupakan jenis kesalahan yang paling dominan dilakukan siswa.
\end{abstract}

Kata Kunci: kesalahan siswa, operasi hitung bilangan cacah, prosedur newman, soal cerita

\section{ANALYSIS OF ELEMENTARY STUDENTS' ERRORS IN SOLVING THE WORD PROBLEM OF WHOLE NUMBERS OPERATION BASED ON NEWMAN'S PROCEDURE}

\begin{abstract}
This study aims to analyze errors in solving the word problem of whole numbers operationof 2nd gradersin GMIT Oenesu Elementary School, Kupang, NTT. The research method used is qualitative descriptive, namely by describing written test answers and student interviews based on error criteria according to Newman. The subjects in this study were 11 students of GMIT Oenesu Elementary School, Kupang, NTT with 4 interviewed subjects. The selection of 4 subjects was carried out by purposive sampling technique, namely by choosing subjects based on the coonsideration that students had received the material, errors were made, and were able to communicate the results of their work. The instruments used are written tests and interview guidelines that have been validated. The results of this study found that 10 out of 11 students made at least one mistakein solving the problem. In addition, the results of this study also showed that the mistakes made by students related to (1) the errors on understanding the problem i.e. students are unable to identify known and asked information, (2) errors on transforming problems characterized by students errors in writing mathematical symbolic representations of the given problem, (3) errors in process skills that students are unable to solve the given problem with the correct settlement procedure, and (4) the errors in writing the final answer is that the students do not write precisely the final conclusion of the given problem. Furthermore, errors of misunderstanding and transforming problems is the most dominant type of mistake students make.
\end{abstract}

Keywords: student errors, whole numbers operation, newman procedures, word problem 


\section{Pendahuluan}

Pendidikan merupakan salah satu aspek kehidupan terpenting dan berdampak besar bagi kehidupan manusia. Hal tersebut dikarenakan pendidikan dapat membentuk karakter dan menambah wawasan bagi setiap orang yang mengembannya. Hasibuan, Saragih dan Amry (2018) menyatakan bahwa pendidikan sebagai proses membentuk karakter dan pola piker yang relevan dengan dunia. Pendidikan yang berkarakter diyakini mampu menghadirkan iklim kompetisi tersendiri pada bidang pendidikan (Peranginangin, Saragih dan Siagian, 2019). Lebih lanjut, dalam pembukaan UUD 1945 menyebutkan upaya mencerdaskan kehidupan bangsa sebagai cita-cita yang perlu dicapai melalui pencapaian tujuan pendidika nasional yaitu mengembangkan manusia Indonesia seutuhnya. Manusia yang utuh berarti manusia yang beriman, bertaqwa terhadap Tuhan yang Maha Esa dan berbudi pekerti luhur, memiliki pengetahuan dan keterampilan, serta tanggung jawab kemasyarakatan dan kebangsaan. Melalui pendidikan diharapkan dapat membentuk generasi bangsa yang berkompetensi secara akademik, matang secara karakter, terampil, peduli lingkungan, dan berjiwa nasionalisme. Hal ini dapat dicapai melalui pelaksanaan pembelajaran yang berkualitas di sekolah. Pada akhrinya, tujuan dari pendidikan nasional bangsa Indonesia yang termuat dalam UUD 1945 dapat tercapai.

Matematika sebagai salah satu mata pelajaran di sekolah dasar berisi muatan terkait pola keteraturan, struktur terorganisir dalam suatu bidang kehidupan yang mempelajari hakikat pemahaman terhadap pola perubahan yang terjadi pada dunia nyata dan dalam pikiran manusia (Dwidarti, dkk, 2019). Matematika berperan sangat penting bagi Pendidikan secara umum baik pada aspek-aspek yang bersifat teknis dan ilmiah maupun dalam kaitannya dengan bidang ilmu lain dan aplikasinya dalam konteks kehidupan seharihari. Dengan adanya matematika, berbagai persoalan sehari-hari dapat diselesaikan dengan cepat dan sederhana dengan menguraikan persoalan-persoalan tersebut dalam model matematika. Lebih lanjut, Permendiknas Nomor 22 Tahun 2006 untuk satuan pendidikan dasar dan menengah menyebutkan bahwa pembelajaran matematika dimaksudkan untuk membekali peserta didik dengan kemampuan berpikir tingkat tinggi (logis, analitis, sistematis, kritis dan kreatif) serta kemampuan bekerja sama. Selain itu, pembelajaran matematika di SD juga berorientasi pada pemahaman konsep matematika, keterampilan memecahkan masalah, mengkomunikasikan gagasan matematikannya dan membentuk sikap terhadap matematika dalam kehidupan sehari-hari (Rostika \& Junita, 2017).

Salah satu cara untuk membiasakan siswa dengan pemecahan masalah matematika adalah dengan menggunakan soal cerita. Meskipun tidak semua soal cerita adalah masalah matematika, tetapi bisanya soal cerita dapat menjadi representasi masalah matematika yang dapat membantu siswa menumbuhkembangkan kemampuan berpikir logis dan kritis. Soal cerita dapat membantu siswa melatih kemampuan menafsirkan, memahami, analisis, dan sekaligus memecahkan masalah. Lebih lanjut, soal cerita dapat digunakan untuk mengetahui kemampuan siswa dalam menyelesaikan soal. Menurut Hartini, dkk (2008), soal cerita dapat menjadi soal yang merepresentasikan masalah sehari-hari. Dalam hal ini, soal cerita dapat disajikan dalam cerita pendek yang relevan dan merepresentasikan masalah sehari-hari (Abidin dalam Ariestina dkk, 2014) Adapun pemecahan masalah matematika adalah suatu proses yang menuntut pemahaman konsep, keterampilan, dan proses matematika dalam menyelesaiakn masalah yang diberikan (Roebyanto, 2017). Dengan kata lain, soal cerita dalam pembelajaran matematika dapat menjadi salah satu cara untuk membelajarkan matematika berbasis masalah sehingga dapat mendorong proses berpikir siswa yang berorientasi pada pemecahan masalah juga. Namun demikian, tidak semua siswa dapat dengan mudah mengerjakan soal cerita. Bahkan penyelesaian soal cerita (word problems) sering kali menjadi permasalahan yang dijumpai pada siswa Sekolah Dasar.

Muncarno (Sudirman, dkk, 2019) mengatakan bahwa kesulitan siswa dalam menyelesaikan soal cerita dikarenakan ketidakcermatan siswa dalam membaca, memahami, dan mengidentifikasi informasi pada soal, serta ketidaktepatan dalam menentukan apa yang ditanyakan dan cara menyelesaikannya. Selain itu, siswa juga mengalami masalah atau kesulitan dalam menyelesaikan soal cerita di antaranya masalah yang terkait dengan kata-kata, kesulitan kognitif terkait operasi dan prosedur yang tidak biasa (Bergeson, 2000). Lebih lanjut, kesulitan kognitif yang dialami siswa juga didasari oleh faktor lain seperti posisi pertanyaan dalam masalah soal cerita, tingkat spesifik dalam katakata dalam masalah, besaran angka, jumlah tindakan isyarat dari operasi yang digunakan dalam penyelesaian, dan ketersediaan alat peraga konkrit (Fuson, 1992).

Salah satu kesulitan dalam menyelesaikan soal cerita matematika pada siswa SD adalah pemecahan soal cerita operasi hitung bilangan 
cacah. Hal ini setidaknya juga dialami siswa kelas II SD GMIT Oenesu Kabupaten Kupang. Berdasarkan wawancara kepada guru wali kelas II SD GMIT Oenesu pada tanggal 2 Juli 2021 diperoleh data bahwa tingkat pemahaman siswa untuk soal cerita masih rendah. Namun, ketertarikan siswa dalam menerima pembelajaran numerasi lebih tinggi dibandingkan dengan pembelajaran literasi. Karena ketertidaktarikan siswa terhadap soal yang berbentuk narasi maka siswa kelas II SD GMIT Oenesu banyak mengalami kesulitan dalam menyelesaikan soal cerita operasi hitung bilangan cacah. Oleh karena itu peneliti tertarik untuk meneliti kesalahan yang dilakukan siswa kelas II SD GMIT Oenesu dalam menyelesaikan soal cerita operasi hitung berdasarkan prosedur Newman.

Kesalahan-kesalahan umum yang ditemukan pada peserta didik kelas II SD GMIT Oenesu dalam menyelesaikan operasi hitung bilangan cacah juga sesuai dengan kesalahankesalahan yang dikemukakan oleh teori Newman yaitu mencakup kesalahan membaca, kesalahan memahami, kesalahan transformasi dan kesalahan keterampilan proses. Adapun kesalahan yang dilakukan siswa dapat diidentifikasi saat siswa menyelesaikan masalah dalam bentuk soal cerita serta melalui wawancara pada siswa. Newman berpendapat bahwa penyelesaian masalah matematika melalui beberapa tahapan seperti membaca (reading), memahami (comprehension), transformasi (transformation), keterampilan proses (process skill), dan penulisan jawaban (encoding). Analisis kesalahan siswa berdasarkan teori Newman dimaksudkan untuk mengidentifikasi secara persis jenis dan deskripsi kesalahan siswa. Oleh karena itu, teori Newman dijadikan acuan dalam penelitian ini untuk menganalisis kesalahan siswa dan mengetahui penyebabnya.

Berdasarkan pemaparan di atas, adapun tujuan dari penelitian ini yaitu untuk menganalisis dan mendeskripsikan kesalahan dalam menyelesaikan soal cerita operasi hitung bilangan cacah pada siswa kelas II SD GMIT Oenesu berdasarkan prosedur Newman. Analisis kesalahan siswa pada penelitian ini diharapkan dapat memberikan informasi dan landasan bagi pengembangan treatment lanjutan untuk bisa meremediasi dan meminimalisir kesalahankesalahan siswa tersebut.

Pada penelitian ini, peneliti menganalisis kesalahan-kesalahan yang dilakukan oleh siswa SD dalam menyelesaikan soal cerita operasi hitung bilangan cacah pada operasi penjumlahan, pengurangan, perkalian, dan pembagian. Penelitian seperti ini masih sejatinya telah banyak dilakukan, terutama pada jenjang SMP dan SMA. Sementara itu, penelitian yang menganalisis kesalahan siswa dalam menyelesaikan soal cerita pada jenjang SD di NTT masih jarang dilakukan. Hal ini karena sebagian besar guru masih belum terbiasa dalam mengintegrasikan berbagai konteks dan soal cerita dalam pembelajaran matematika. Sehingga melalui penelitian ini, diharapkan ada suatu sudut pandang yang baru terkait berbagai kesalahan dan deskripsi kesalahan siswa dalam menyelesaiakan soal cerita operasi hitung sederhana yang pada akhirnya dapat menjadi acuan untuk merumuskan treatment lanjutan.

\section{Metode Penelitian}

Penelitian ini dilakukan di SD GMIT Oenesu Kabupaten Kupang, NTT. Metode penelitian yang digunakan adalah deskriptif kualitatif yaitu dengan menganalisis jawaban tes tertulis dan wawancara siswa berdasarkan kriteria kesalahan menurut Newman. Penelitian Kualitatif adalah suatu penelitian yang ditujukan untuk menganalisis fenomena, peristiwa, atau pemikiran siswa secara individual maupun kelompok (Sukmadinata, 2009). Dalam hal ini, fenomena yang dimaksud adalah kesalahan siswa dalam menyelesaikan soal cerita matematika. Penelitian ini dimaksudkan untuk mengungkap dan mendeskripsikan kesalahan siswa kelas II SD GMIT Oenesu dalam menyelesaikan soal cerita operasi hitung bilangan cacah.

Subjek dalam penelitian ini adalah siswa kelas II SD GMIT Oenesu yang berjumlah 11 orang dengan subjek yang diwawancarai sebanyak 4 orang. Pemilihan 4 subjek dilakukan dengan teknik purposive sampling yaitu dengan memilih subjek atas dasar pertimbangan siswa sudah mendapatkan materi, adanya kesalahan yang dilakukan, dan siswa mampu mengkomunikasikan hasil kerjanya. Adapun objek dalam penelitian ini adalah kesalahan dan penyebab kesalahan siswa ketika menyelesaikan soal cerita operasi hitung bilangan cacah.

Pengumpulan data dilakukan menggunakan tes tertulis dan wawancara dengan instrumen yang digunakan berupa soal tes tertulis yang terdiri atas 5 butir soal cerita tentang materi bilangan cacah dan pedoman wawancara sesuai dengan kesalahan Newman yang telah divalidasi oleh 1 orang Guru Matematika SD GMIT Oenesu kelas II dan 2 orang Dosen Program Studi Pendidikan Matematika Universitas Nusa Cendana Kupang. Lembar validasi berisi tentang kesesuaian validasi isi, validasi konstruksi, dan bahasa soal. Adapun hasil validasi oleh validator menyatakan instrument 
layak digunakan dengan revisi minor pada aspek kebahasaan. Instrumen utama dalam penelitian ini adalah peneliti, sedangkan instrumen sekundernya berupa soal cerita dengan materi bilangan cacah sebanyak 5 soal. Tes tertulis pada penelitian dilakukan untuk mengumpulkan data terkait kesalahan siswa dan wawancara pada penelitian ini berfungsi untuk mendapatkan informasi tambahan yakni penyebab kesalahan siswa. Validitas data pada penelitian ini dilakukan melalui triangulasi teknik, yaitu membandingkan data dari subjek yang sama melalui Teknik yang berbeda yaitu tes dan wawancara. Data dalam penelitian ini, yaitu (1) jawaban tes soal cerita siswa dan (2) hasil wawancara. Hasil dari tes soal cerita pada penelitian ini adalah jawaban siswa dalam menyelesaikan soal cerita materi bilangan cacah. Hasil wawancara siswa diperoleh dari wawancara peneliti dengan siswa terkait dengan hasil tes soal cerita. Analisis kesalahan pada penelitian ini yaitu analisis kesalahan berdasarkan prosedur Newman yang meliputi kesalahan membaca, kesalahan memahami, kesalahan transformasi, kesalahan keterampilan proses, dan kesalahan penulisan jawaban. Adapun indikator kesalahan menurut prosedur Newman (Suyitno dan Suyitno, 2015) disajikan pada tabel 1 .

Teknik analisis data yang digunakan dalam penelitian ini meliputi reduksi data, penyajian data, dan penarikan kesimpulan. Reduksi data berarti penyederhanaan data yang diperoleh dari tes tertulis dan wawancara. Penyajian data berarti menyajikan data yang peroleh dengan cara mendeskripsikan kesalahan siswa. Sementara pada tahap terakhir dilakukan penarikan kesimpulan dari data-data yang telah diperoleh.

Tabel 1. Indikator Kesalahan Siswa Menurut Prosedur Newman

\begin{tabular}{lrl}
\hline \multicolumn{1}{c}{ Jenis Kesalahan } & & \multicolumn{1}{c}{ Indikator Kesalahan } \\
\hline Kesalahan Membaca & 1. & $\begin{array}{l}\text { Siswa dapat membaca soal cerita yang diberikan tetapi } \\
\text { tidak memahami arti soal cerita }\end{array}$ \\
Kesalahan Memahami & 2. & $\begin{array}{l}\text { Siswa salah atau tidak mengetahui informasi penting } \\
\text { yang diketahui dari soal cerita }\end{array}$ \\
& 3. & $\begin{array}{l}\text { Siswa salah atau tidak mengetahui pertanyaan yang } \\
\text { harus diselesaiakn dari soal cerita }\end{array}$ \\
Kesalahan Transformasi & 4. & $\begin{array}{l}\text { Siswa tidak mampu menemukan konsep, strategi, dan } \\
\text { prosedur yang tepat untuk menyelesaikan soal cerita }\end{array}$ \\
Kesalahan Keterampilan Proses & 5. & $\begin{array}{l}\text { Siswa tidak dapat melakukan proses perhitungan } \\
\text { matematika dengan benar }\end{array}$ \\
Kesalahan Penulisan Jawaban & 6. & Siswa tidak dapat menunjukan jawaban yang benar \\
\hline
\end{tabular}

\section{Hasil dan Pembahasan}

Seluruh subjek penelitian sudah menyelesaikan tes yang diberikan. Berdasarkan hasil tes terhadap 11 orang siswa, 10 diantaranya melakukan kesalahan minimal pada salah satu soal tes. Dari 10 orang siswa yang melakukan kesalahan diambil 4 siswa yang dijadikan subjek penelitian. Kemudian pada keempat siswa ini dilakukan wawancara. Berikut ini data hasil pemecahan soal cerita materi operasi hitung bilangan cacah berdasarkan prosedur Newman.

\subsection{Analisis terhadap subjek pertama (S1)}

Dari 5 soal tes yang diberikan, S1 hanya melakukan kesalahan pada soal nomor 3. Berdasarkan Gambar 1 dapat dilihat bahwa subjek mampu memahami masalah sehingga dapat menyatakan operasi yang diminta dalam soal cerita tersebut. Namun demikian, hasil pekerjaan siswa juga menunjukkan bahwa subjek gagal mengoperasikan dan menemukan hasil yang tepat dari representasi simbolik yang dibuat.

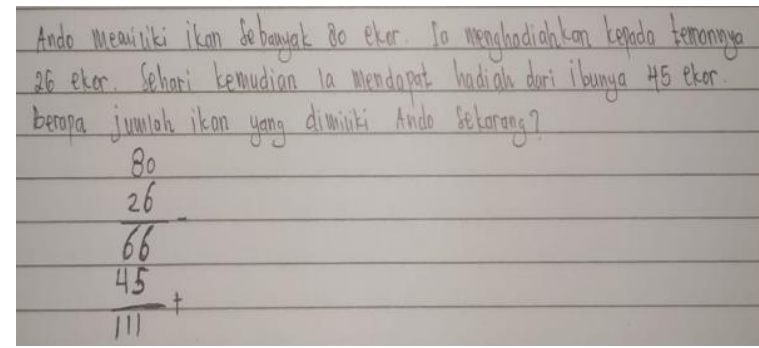

Gambar 1. Pemecahan soal nomor 3 oleh S1

P : “Oke. Sudah benar. Jadinya bagaimana dek?"

S : “Jadinya, 80-26 dulu Bu. Setelah itu baru ditambah 45."

P : "Iya betul. Tetapi disini 80-26 nya salah. Dari 80-26 yang dioperasikan lebih dahulu apa?"

S : " $0-6$ Bu."

$\mathrm{P}$ : "0 -6 berapa?"

$\mathrm{S}$ : "Tidak bisa Bu. Jadi pakai sistem pinjam Bu."

P : "Iya tepat sekali. Tetapi adek punya disini $0-6=6$. Kenapa bisa salah?"

$\mathrm{S}$ : "Kurang fokus Bu." 
Berdasarkan hasil pekerjaan siswa dan dipertegas oleh paparan hasil wawancara siswa dapat disajikan analisis kesalahan siswa menurut prosedur Newman sebagai berikut. (1) siswa sudah bisa membaca soal cerita yang diberikan, (2) siswa sudah memahami soal karena siswa sudah mengetahui apa yang diketahui dan yang ditanyakan dari soal yang ditandai dengan siswa dapat menyatakan operasi yang diminta dalam soal cerita tersebut, (3) siswa sudah bisa mentransformasikan soal karena siswa dapat menuliskan representasi simbolik matematika dari soal yang diberikan dan sudah mengetahui operasi apa yang dapat digunakan untuk menyelesaikan soal yaitu operasi pengurangan dan penjumlahan, (4) siswa melakukan kesalahan dalam keterampilan berproses yakni siswa salah dalam mengoperasikan pengurangan $0-6$ yang disebabkan karena kurang teliti dan fokus padahal sebenarnya siswa sudah bisa dalam pengurangan. Hal ini berdampak juga pada penulisan jawaban akhir yang salah.

\subsection{Analisis terhadap subjek kedua (S2)}

Dari 5 soal tes yang diberikan, S2 melakukan kesalahan pada semua nomor soal yang diberikan

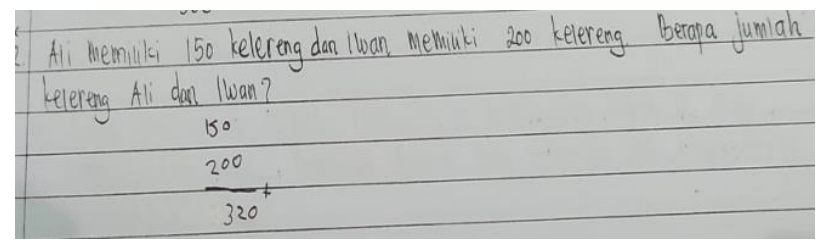

Gambar 2. Pemecahan soal nomor 1 oleh S2

Berdasarkan Gambar 2 di atas dapat dilihat bahwa subjek mampu memahami masalah di atas sehingga siswa dapat menyatakan operasi yang diminta dari soal cerita tersebut. Namun dari gambar di atas pula dapat dilihat bahwa subjek jugagagal mengoperasikan dan menemukan hasil yang tepat dari representasi simbolik yang telah dibuat.

$$
\begin{aligned}
& \text { P : "Ya sudah benar. Tetapi kenapa 150+200 = } \\
& \text { S : "Dari belakang Bu." } \\
& \text { P : "Coba hitung ulang lagi." } \\
& \mathrm{S} \text { : "Sudah Bu, hasilnya 350." } \\
& \text { P : "Kenapa kemarin ketika kerja hasilnya 320?" } \\
& \mathrm{S} \text { : "Saya kurang teliti Bu. Saya hitung hasilnya } \\
& 5 \text { tetapi saya salah tulis jadinya } 2 \text { Bu." }
\end{aligned}
$$

Berdasarkan hasil pekerjaan siswa dan dipertegas oleh paparan hasil wawancara siswa dapat disajikan analisis kesalahan siswa menurut prosedur Newmansebagai berikut. (1) siswa sudah bisa membaca soal cerita yang diberikan, (2) siswa sudah memahami soal karena siswa sudah mengetahui apa yang diketahui dan yang ditanyakan dari soal yang ditandai dengan siswa dapat menyatakan operasi yang diminta dari soal cerita tersebut, (3) siswa sudah bisa mentransformasikan soal karena siswa dapat menuliskan representasi simbolik matematika dari soal yang diberikan dan sudah mengetahui operasi apa yang dapat digunakan untuk menyelesaikan soal yaitu operasi penjumlahan, (4) siswa tidak melakukan kesalahan dalam keterampilan berproses karena siswa mampu menyelesaikan soal dengan prosedur penyelesaian matematika yang benar, dan (5) siswa salah dalam menuliskan jawaban akhir karena sebenarnya hitungannya sudah benar tetapi dalam menuliskan jawaban akhir siswa kurang teliti dan salah tulis yang seharusnya hasilnya 350 ditulis 320 sehingga jawaban akhirnyapun salah.

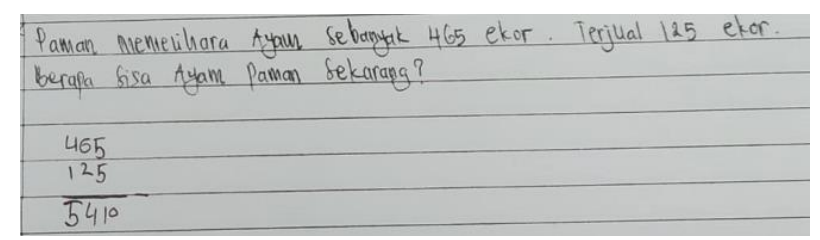

Gambar 3. Pemecahan soal nomor 2 oleh S2

Berdasarkan Gambar 3 diatas dapat dilihat bahwa subjek mampu memahami masalah di atas sehingga dapat menyatakan operasi yang diminta dari soal cerita tersebut tetapi subjek gagal atau salah dalam mengoperasikan dan menemukan hasil yang tepat dari representasi simbolik yang telah dibuat.

\footnotetext{
P : "Iya benar sekali. Jadinya dari soal tadi dapat ditulis bagaimana?"

S : "Ditulis 465 - 125 Bu."

P : "Iya benar. Lalu berapa hasil dari 465-125? Coba adik cakar ulang lagi."

S : "340 Bu."

P : "Iya hasilnya adalah 340. Tetapi dari pekerjaan adik punya kemarin kenapa hasilnya 5410? Disini adik kerja pakai pengurangan bersusun kan kemarin?"

S : "Maaf Ibu. Iya Ibu pakai pengurangan bersusun."

$\mathrm{P}$ : "Kalau pakai pengurangan bersusun hitungnya mulai dari depan atau belakang?"

S : "Dari belakang Bu."

$\mathrm{P}$ : "Iya sudah benar. Jadinya yang dioperasikan terdahulu itu apa?"

S : "5-5 lebih dahulu Bu."

$\mathrm{P}$ : "5-5 berapa?"

$\mathrm{S}$ : "0 Ibu."

$\mathrm{P}$ : "Iya benar. Tetapi dari pekerjaan adik punya kemarin kenapa bisa hasilnya 10?"

S : "Maaf ibu. Saya langsung jumlahkan kemarin, saya tidak perhatikan kalau ini pengurangan $\mathrm{Bu} . "$
} 
Berdasarkan hasil pekerjaan siswa dan dipertegas oleh paparan hasil wawancara siswa dapat disajikan analisis kesalahan siswa menurut prosedur Newman sebaagai berikut. (1) siswa sudah bisa membaca soal cerita yang diberikan, (2) siswa sudah memahami soal karena siswa dapat menentukan apa yang diketahui dan ditanyakan dari soal yang ditandai dengan siswa dapat menyatakan operasi yang diminta dari soal cerita tersebut, (3) siswa sudah bisa mentransformasikan soal karena siswa dapat menuliskan representasi simbolik matematika dari soal yang diberikan yang ditandai dengan penggunaan operasi pengurangan dari 465-125, (4) siswa melakukan kesalahan dalam keterampilan berproses karena siswa tidak mampu menyelesaikan soal dengan prosedur penyelesaian matematika yang benar dimana siswa keliru pada saat melakukan operasi pengurangan(pengurangan bersusun) yakni bukannya mengurangkan 465-125, siswa malah menjumlahkan 465-125 dan hasil penjumlahannya juga salah sehingga jawaban akhirnyapun salah.

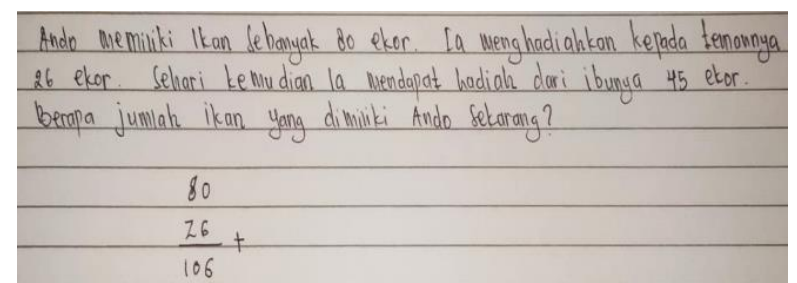

Gambar 4. Pemecahan soal nomor 3 oleh S2

Berdasarkan Gambar 4 di atas dapat dilihat bahwa subjek gagal memahami masalah yang diberikan. Hal ini ditandai dengan tidak mampunya siswa dalam menentukan secara tepat unsur-unsur yang diketahui dan operasi yang digunakan dalam menyelesaikan soal cerita tersebut, sehingga berdampak pada salahnya jawaban akhir yang diperoleh siswa. Ketidakmampuan siswa dalam memahami masalah juga dipertegas melalui cuplikan wawancara yang disajikan dalam cuplikan wawancara subjek sebagai berikut.

$\mathrm{P}$ : "Dari soal yang sudah adik baca. Adik sudah paham atau tidak? Soal ini menggunakan operasi apa? Penjumlahan, pengurangan, perkalian, atau pembagian?"

S : "Tidak Ibu."

$\mathrm{P}$ : "Begini dari soal yang diberikan. Pertama, kita perhatikan kalimat "Ando memiliki ikan sebaanyak 80 ekor kemudian Ia hadiahkan ke temannya 26 ekor". Ini menggunakan operasi apa?"

S : "Pengurangan Ibu."

$\mathrm{P}$ : "Kenapa Pengurangan?"

$\mathrm{S}$ : "Karena jumlah ikan yang dimiliki Ando berkurang ketika dia berikan ketemannya 26 ekor Bu."

P : "Iya betul. Jadinya kita dapat tulis bagaimana?"
S : " $80-26$ Bu."

$\mathrm{P}$ : "Iya benar sekali. Kita dapat tulis 80-26. Kemudian setelah itu dari kalimat "Ando mendapat ikan dari ibunya sebanyak 45 ekor". Jadinya ikannya betambah atau tidak?"

S : "Bertambah Ibu."

P : "Kalau bertambah jumlahnya kita pakai operasi apa?"

S : "Operasi penjumlahan Ibu."

P : "Iya betul sekali. Sehingga dari soal ini kita dapat tulis bagaimana?"

S : "Dapat ditulis 80-26+45 Bu."

$\mathrm{P}$ : "Iya jadi begini ya. Baru setelah itu dihitung. Paham?"

S : "Paham Bu."

Berdasarkan hasil pekerjaan siswa dan paparan hasil wawancara siswa dapat disajikan analisis kesalahan siswa menurut prosedur Newman sebaagai berikut. (1) siswa sudah bisa membaca soal cerita yang diberikan, (2) siswa belum memahami soal karena tidak tahu apa yang diketahui dan yang ditanyakan dari soal yang ditandai dengan tidak mampunya siswa dalam menyatakan operasi yang diminta dari soal cerita,(3)siswa salah mentransformasikan soal karena siswa tidak dapat menuliskan representasi simbolik matematika dari soal cerita dimana dari soal cerita yang diberikan representasi simbolik yang ditulis siswa yaitu $80+26$ padahal representasi yang benar adalah 80-26 + 45, (4) karena siswa sudah salah dalam memahami dan mentransformasi soal maka siswa juga salah dalam menyelesaikan soal sesuai dengan prosedur penyelesaian matematika yang benar yang kemudian berdampak pada jawaban akhir yang salah.

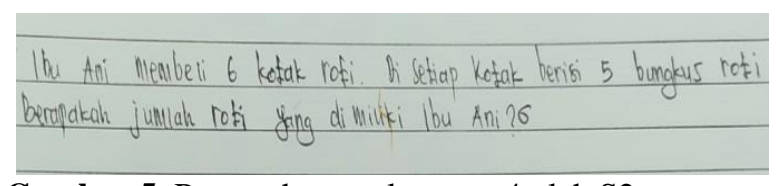

Gambar 5. Pemecahan soal nomor 4 oleh S2

Berdasarkan Gambar 5 di atas dapat dilihat bahwa subjek gagal memahami masalah yang diberikan. Hal ini ditandai dengan tidak mampunya siswa dalam menyatakan operasi yang diminta dari soal cerita yang berdampak pada salahnya jawaban akhir yang diperoleh siswa.

P : "Dari soal yang sudah adik baca. Adik sudah paham atau tidak?"

S : "Tidak Ibu."

P : "Dari soal, kita dapat mengetahui bahwa ibu Ani membeli 6 kotak roti, lalu setiap kotaknya ini berisi 5 bungkus roti. Nah dari soal ini kira-kira menurut adik, ini 
menggunakan operasi apa? Penjumlahan, pengurangan, perkalian, atau pembagian?"

S : "Tidak tahu Ibu."

$\mathrm{P}$ : "Begini, kan ada 6 kotak roti, terus setiap kotak ada 5 bungkus roti. Maka kalau 6 kotak roti isinya ada $6 \times 5$, berapa hasilnya?"

S : "30 Bu."

P : "Iya benar. Jadinya, banyaknya roti yang dibeli Ibu Ani adalah 30 bungkus roti."

Berdasarkan hasil pekerjaan siswa dan paparan hasil wawancara siswa dapat disajikan analisis kesalahan siswa menurut prosedur Newman sebagai berikut. (1) siswa sudah bisa membaca soal cerita yang diberikan, (2) siswa belum memahami soal karena siswa tidak mengetahui apa yang diketahui dan yang ditanyakan dari soal yang ditandai dengan tidak mampunya siswa dalam menyatakan operasi yang diminta dari soal cerita,(3) siswa gagal atau salah mentransformasikan soal karena siswa tidak dapat menuliskan representasi simbolik matematika dari soal yang diberikan, (4) karena siswa tidak dapat atau salah dalam memahami dan menstransformasi soal maka siswa juga melakukan kesalahan dalam keterampilan berproses sehingga jawaban akhirnyapun salah juga.

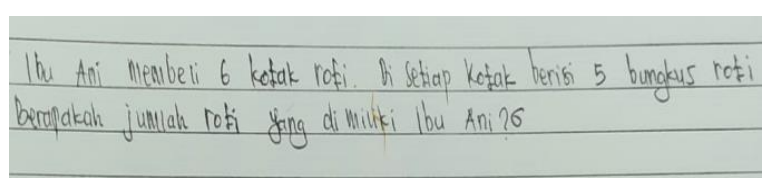

Gambar 6. Pemecahan soal nomor 5 oleh S2

Berdasarkan Gambar 6 di atas dapat dilihat bahwa subjek mampu memahami masalah di atas sehingga dapat menyatakan operasi yang diminta dari soal cerita tersebut tetapi subjek gagal atau salah dalam mengoperasikan dan menemukan hasil yang tepat dari representasi simbolik yang telah dibuat.

$$
\begin{aligned}
& \text { P : "Iya betul Sekali. Jadi dari soal operasinya } \\
& \text { dapat kita tulis bagaimana?" } \\
& \text { S : "Dapat ditulis } 20: 5 \text { Bu." } \\
& \text { P : "Hasil dari } 20 \text { : } 5 \text { berapa?" } \\
& \text { S : "Tidak tahu Ibu." } \\
& \mathrm{P} \text { : "Begini, } 20 \text { : } 5 \text { itu maksudnya } 20 \text { permen }
\end{aligned}
$$

Berdasarkan hasil pekerjaan siswa dan paparan hasil wawancara siswa dapat disajikan analisis kesalahan siswa menurut prosedur Newman sebagai berikut. (1) siswa sudah bisa membaca soal cerita yang diberikan, (2) siswa sudah memahami soal karena siswa sudah mengetahui apa yang diketahui dan ditanya dari soal yang ditandai dengan mampunya siswa dalam menyatakan operasi yang diminta dari soal cerita tersebut, (3) siswa sudah bias mentransformasikan soalkarena siswa dapat menuliskan representasi simbolik matematika dari soal yang diberikan yaitu 20 : 5, (4) siswa melakukan kesalahan dalam keterampilan berproses yang disebabkan karena siswa tidak tahu tentang operasi pembagian. Hal ini berdampak kepada jawaban akhir yang salah juga.

\subsection{Analisis terhadap subjek ketiga (S3)}

Dari 5 soal tes yang diberikan, S3 hanya melakukan kesalahan pada soal nomor 2. Gambar 7 berikut menunjukkan kesalahan yang dimaksud.

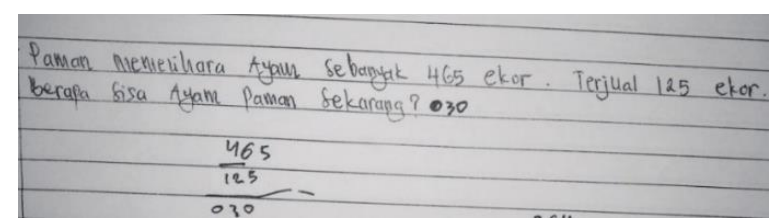

Gambar 7. Pemecahan soal nomor 2 oleh S3

Berdasarkan Gambar 7 di atas dapat dilihat bahwa subjek mampu memahami masalah di atas sehingga dapat menyatakan operasi yang diminta dari soal cerita tersebut tetapi subjek gagal atau salah dalam mengoperasikan dan menemukan hasil yang tepat dari representasi simbolik yang telah dibuat.

$\mathrm{P}$ : "Iya benar. Tetapi dari jawaban pekerjaan adik kemarin salah. Nah Adik kemarin kerjanya pakai operasi pengurangan bilangan bersusun. Kalau pengurangan bilangan bersusun hitungnya mulai dari depan atau belakang?"

S : "Dari belakang Ibu."

P : "Jadi yang dioperasikan terlebih dahulu yaitu?"

S : "5-5 Bu."

P : "Hasilnya berapa?"

S : "0 Ibu."

P : "Iya benar. Setelah itu?"

S : "6-2 kemudian baru 4-1 Ibu."

P : "Kalau 6-2 berapa dan 4-1 berapa?"

S : " $6-2=4$ dan 4-1 = 3 Ibu."

$\mathrm{P}$ : "Iya benar. Tetapi kenapa kemarin ketika kerja bisa salah disini?"

S : "Saya kurang teliti Ibu."

Berdasarkan hasil pekerjaan siswa dan paparan hasil wawancara siswa dapat disajikan analisis kesalahan siswa menurut prosedur Newman sebagai berikut. (1) siswa sudah bisa membaca soal, (2) siswa sudah memahami soal cerita karena siswa sudah mengetahui apa yang 
diketahui dan ditanyakan dari soal yang ditandai denganpenyusunan bilangan dengan pemberian symbol (-), (3) siswa sudah bisa menstransformasikan soal karena siswa dapat menuliskan representasi simbolik matematika dari soal yang diberikan yaitu 465-125 yang tulis secara bersusun, (4) siswa melakukan kesalahan keterampilan berproses dimana siswa tidak mampu menyelesaikan soal yang diberikan dengan prosedur penyelesaian yang benaryakni salah dalam menjawab hasil pengurangan angka 6 dikurang 2 dan angka 4 dikurang 1 sehingga berdampak pada jawaban akhir yang salah.

\subsection{Analisis terhadap subjek keempat (S4)}

Dari 5 soal tes yang diberikan, S4 melakukan kesalahan pada soal nomor 3, 4 dan 5.

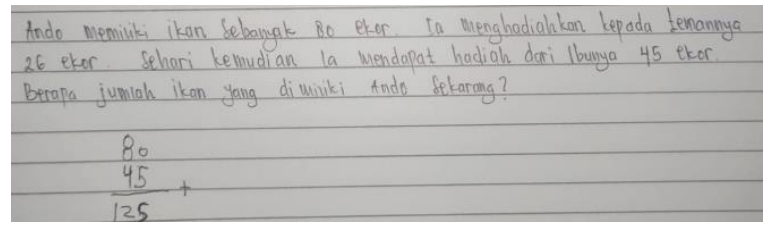

Gambar 8. Pemecahan soal nomor 3 oleh S4

Berdasarkan Gambar 8 di atas dapat dilihat bahwa subjek gagal memahami masalah di atas sehingga belum mampu menyatakan operasi yang diminta dari soal cerita tersebut. Hal ini juga berdampak pada salahnya mentransformasikan soal, menyelesaikan soal dengan prosedur penyelesaian yang benar, dan juga jawaban akhir yang diperoleh siswa.

P : "Karena Adik bilang sudah paham menurut adik dari kalimat pertama "Ando memiliki 80 ekor ikan lele kemudian Ia menghadiahkan kepada temannya 26 ekor" dan kalimat kedua "Sehari kemudian Ia mendapat hadiah dari ibunya 45 ekor ikan Mas". Kalimat pertama dan kedua ini menggunakan operasi apa? Penjumlahan, pengurangan, perkalian, atau pembagian?"

S : "Penjumlahan dan penjumlahan Ibu."

P : "Kenapa kalimat pertama adik bilang menggunakan operasi penjumlahan? Darimana adik tahu ini menggunakan operasi penjumlahan?"

S : "Tidak tahu Ibu."

P : "Begini dek. Ando memiliki 80 ekor ikan lele kemudian Ia menghadiahkan kepada temannya 26 ekor. Nah kalau ando menghadiahkan 26 ekor ikan lele ke temannya ikan yang dimiliki Ando bertambah atau berkurang?"

S : "Berkurang Bu."

P : "Nah kalau berkurang, berarti kita pakai operasi pengurangan. Jadi, operasi pengurangannya dapat ditulis bagaimana?"

S : " $80-26$ Bu."
P : "Iya benar. Tetapi dijawaban adik kemarin salah tulisnya, adik punya langsung tulis $80+45$. Seharusnya bagaimana?"

S : "80-26 dulu baru ditambah 45 Bu."

Berdasarkan hasil pekerjaan siswa dan paparan hasil wawancara siswa dapat disajikan analisis kesalahan siswa menurut prosedur Newman sebagai berikut. (1) siswa sudah bisa membaca soal, (2) siswa belum memahami soal karena siswa tidak mengetahui apa yang diketahui dan ditanyakan dari soal (siswa tidak mengetahui bahwa soal ini merupakan kombinasi penjumlahan dan penguarangan), (3) siswa salah dalam menstransformasikan soal karena siswa tidak dapat menuliskan representasi simbolik matematika dari soal yang diberikan yaitu seharusnya $80-26+45$ tetapi siswa langsung menulis $80+45$, (4) siswa salah dalam keterampilan berproses dimana siswa tidak mampu menyelesaikan soal yang diberikan dengan prosedur penyelesaian yang benar. Siswa langsung menjumlahkan bilangan 80 dengan 45 tanpa mengurangi dengan bilangan 26 terlebih dahulu. Hal tersebut di karenakan siswa kurang memahami soal yang diberikan dan salah dalam menstransformasikan soal. Dampak akhirnya, siswa salah dalam menuliskan jawaban akhir.

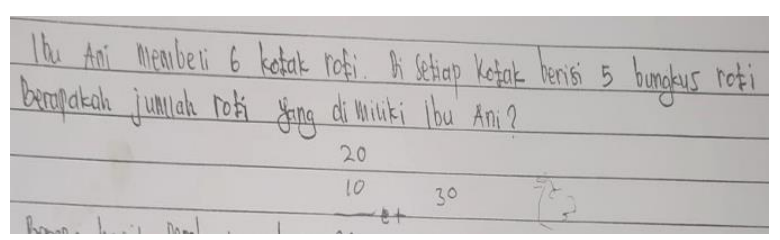

Gambar 9. Pemecahan soal nomor 4 oleh S4

Berdasarkan Gambar 9 di atas dapat dilihat bahwa subjek gagal memahami masalah di atas sehingga belum mampu menyatakan operasi yang diminta dari soal cerita tersebut. Hal ini juga berdampak pada salahnya mentransformasikan soal, menyelesaikan soal dengan prosedur penyelesaian yang benar, dan juga jawaban akhir yang diperoleh siswa.

$\mathrm{P}$ : "Menurut adik dalam ini soal menggunakan operasi apa? Penjumlahan, pengurangan, perkalian, atau pembagian?"

S : "Penjumlahan Ibu."

P : "Darimana adik tahu ini menggunakan operasi penjumlahan?"

S : "Tidak tahu Ibu."

$\mathrm{P}$ : "Jadi begini dari soal kita dapat mengetahui bahwa ibu Ani membeli 6 kotak roti, lalu setiap kotaknya ini berisi 5 bungkus roti. Dari soal ini kita dapat menggunakan operasi perkalian. Nah karena satu kotak roti isniya 5 bungkus roti maka kalau 6 kotak roti isinya ada $6 \times 5=\ldots$ bungkus roti. $6 \times 5$ berapa?"

$\mathrm{S}$ : "Berkurang Bu." 
P : "Nah kalau berkurang, berarti kita pakai operasi pengurangan. Jadi, operasi pengurangannya dapat ditulis bagaimana?"

S : "30 Bu."

P : "Iya benar. Jadinya, banyaknya roti yang dibeli ibu Ani adalah 30 bungkus roti."

Berdasarkan hasil pekerjaan siswa dan paparan hasil wawancara siswa dapat disajikan analisis kesalahan siswa menurut prosedur Newman sebagai berikut. (1) siswa sudah bisa membaca soal, (2) siswa belum memahami soal karena siswa belum mengetahui apa yang diketahui dan yang ditanyakan dari soal yang ditandai dengan belum mampunya siswa menyatakan operasi yang diminta dari soal cerita tersebut, (3) siswa salah mentransformasikan soalkarena siswa tidak dapat menuliskan representasi simbolik matematika dari soal yang diberikan, (4) siwa melakukan kesalahan dalam keterampilan berproses dimana siswa menyelesaikan soal cerita perkalian ini dengan menjumlahkan bilangan 20 dengan 10 yang merupakan bilangan yang tidak terdapat pada soal cerita. Karena hal ini jawaban akhirpun salah.

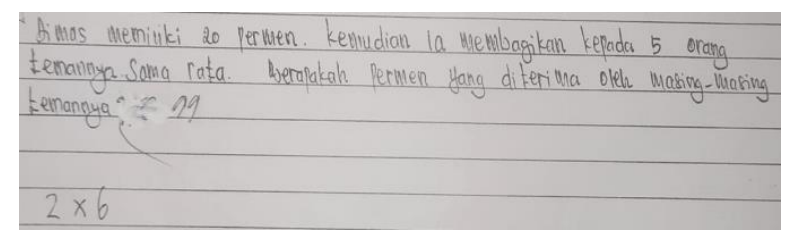

Gambar 10. Pemecahan soal nomor 5 oleh S4

Berdasarkan Gambar 10 di atas dapat dilihat bahwa subjek gagal memahami masalah di atas sehingga belum mampu menyatakan operasi yang diminta dari soal cerita tersebut. Hal ini juga berdampak pada salahnya mentransformasikan soal, menyelesaikan soal dengan prosedur penyelesaian yang benar, dan juga jawaban akhir yang diperoleh siswa.

P : "Dari soal yang sudah adik baca. Adik sudah paham atau tidak soal ini?

S : "Tidak Ibu."

$\mathrm{P}$ : "Begini, dari soal dapat kita ketahui bahwa Dimas memiliki 20 permen dan akan membagikannya kepada 5 orang temannya sama rata. Nah supaya permen yang dimiliki Dimas habis dan setiap temannya mendapatkan jumlah yang sama banyak. Setiap temannya mendapatkan berapa permen?"

S : "Kurang tahu Ibu."

$\mathrm{P}$ : "Menurut adik dalam ini soal menggunakan operasi apa? Penjumlahan, pengurangan, perkalian, atau pembagian?"

S : "Tidak tahu Ibu."

$\mathrm{P}$ : "Soal ini menggunakan operasi pembagian. Karena 20 permen yang dimiliki Geral akan dibagikan kepada 5 temannya sama rata dan dapat dituliskan sebagai $20: 5.20: 5=4$
Sehingga agar permen yang dimiliki Dimas dapat dibagikan kepada 5 temannya sama rata, setiap temannya harus mendapatkan 4 permen. Sudah Paham dek?"

S : "Sedikit Ibu."

Berdasarkan hasil pekerjaan siswa dan paparan hasil wawancara siswa dapat disajikan analisis kesalahan siswa menurut prosedur Newman sebagai berikut. (1) Siswa sudah bisa membaca soal, (2) siswa belum memahami soal yang diberikan karena siswa tidak dapat mengidentifikasi informasi yang diketahui dan ditanyakan dari soal yang diberikan yang ditandai dengan belum mampu menyatakan operasi yang diminta dari soal cerita tersebut, (3) siswa salahatau tidak dapat mentransformasikan soal yang ditandai dengan kesalahan dalam menuliskan representasi simbolik matematika dari cerita yang diberikan dimana siswa merepresentasikan soal menjadi $2 \times 6$ padahal seharusnya $20: 5$, (4) siswa salah melakukan keterampilan berproses dimana dalam menyelesaikan soal cerita pembagian ini siswa menggunakan simbol $(x)$ atau operasi perkalian, angka yang dikalikan juga merupakan angka yang tidak terdapat pada soal yang diberikan. Hal ini berdampak pada jawaban akhir yang salah.

Dari hasil analisis pekerjaan dan wawancara siswa dapat diidentifikasi dan dideskripsikan kesalahan dan penyebab kesalahan siswa dalam menyelesaiakan soal cerita pada materi bilangan operasi hitung bilangan cacah sebagai berikut. (1) Kesalahan memahami masalah seperti tidak mampu mengidentifikasi informasi yang diketahui dan yang ditanyakan dari soal, serta ketidaksesuain informasi yang dituliskan dengan informasi yang ada pada soal cerita. Hal ini sejalan dengan temuan Suyitno \& Suyitno (2015) dalam penelitiannya bahwa kesalahan memahami masalah terjadi saat siswa salah menuliskan informasi yang diketahui dan ditanyakan, atau bahkan tidak menuliskannya sama sekali. (2) Kesalahan transformasi dimana siswa tidak dapat menuliskan representasi simbolik matematika dari soal cerita yang diberikan (tidak dapat menentukan operasi, dan prosedur matematika yang tepat untuk menyelesaikan masalah). Temuan ini sejalan dengan penelitian Abdullah, dkk. (2015) yang menemukan bahwa dalam menyelesaikan masalah siswa juga melakukan kesalahan transformasi yaitu gagal menentukan operasi matematika. Adapun faktor penyebabnya yaitu karena siswa tidak memahami soal dengan baik dan tidak memahami konsep dengan baik. Sebagaiamana juga dikatakan Suyitno \& Suyitno (2015) bahwa kesalahan transformasi terjadi karena kurangnya pemahaman soal, adanya kesalahan konsep, dan kecerobohan 
siswa. (3) Kesalahan keterampilan proses terjadi karena siswa tidak mampu menyelesaikan soal yang diberikan dengan prosedur penyelesaian yang benar seperti kesalahan urutan operasi hitung, salah melakukan perhitungan dan menentukan hasil perhitungan. Abdullah, dkk. (2015) dalam penelitiannya juga menemukan hal serupa bahwa kesalahan perhitungan terjadi saat siswa gagal melakukan prosedur dengan benar. Menurut hasil wawancara kesalahan keterampilan proses disebabkan karena siswa salah dalam memahami masalah dan mentransformasikan soal, dan juga tidak tahu menghitung lebih khususnya operasi pembagian dan perkalian. Selain itu, kesalahan dalam keterampilan berproses juga disebabkan karena kurangnya ketelitian siswa dalam proses perhitungan. Sebagaimana dikatakan Rohmah \& Sutiarso (2018) bahwa kesalahan perhitungan terjadi pada siswa yang tidak berhati-hati dan tidak teliti dalam proses pengerjaan soal. (4) Kesalahan dalam menuliskan jawaban akhir. Kesalahan ini dilakukan karena hampir sebagian siswa melakukan kesalahan pada pemahaman soal dan transformasi soal sehingga hasil akhir dari pekerjaan siswa jugapun menjadi salah. Berdasarkan hasil wawancara kesalahan jenis ini terjadi akibat kesalahan komputasional yang didasari kesalahan siswa dalam memahami dan mentransformasi masalah yang diberikan dalam model matematika yang tepat. Selain itu, kesalahan ini juga terjadi karena siswa yang kurang teliti dalam menuliskan jawaban akhir padahal sudah bisa memecahkan masalah. Hal ini sesuai degan hasil temuan pada penelitian Kristianto, dkk. (2019) siswa memecahkan masalah tetapi tidak menuliskan solusi yang sesuai dan (5) rata-rata kesalahan yang terjadi, disebabkan karena hampir sebagian siswa salah dalam memahami dan mentransformasi masalah dalam soal. Dengan kata lain, kesalahan dalam memahami dan mentransformasi masalah merupakan jenis kesalahan yang paling dominan dilakukan siswa. Hal ini sesuai dengan hasil temuan pada penelitian Mahmudah (2018) yang menyatakan kesalahan pemahaman dan kesalahan transformasi masalah dalam soal lebih dominan dibandingkan kesalahan lainnya.

\section{Kesimpulan}

Berdasarkan hasil penelitian dan pembahasan dapat disimpulkan bahwa kesalahan siswa dalam menyelesaikan soal cerita pada operasi hitung bilangan cacah antara lain sebagai berikut. (1) Kesalahan memahami. Kesalahan ini dilakukan oleh S2 dan S4. Penyebab siswa melakukan kesalahan yaitu siswa tidak memahami maksud dari soal atau tidak mampu mengidentifikasi informasi yang diketahui dan ditanyakan dari soal. (2) Kesalahan transformasi. Kesalahan ini dilakukan oleh S2 dan S4. Penyebab siswa melakukan kesalahan dikarenakan siswa kurang memahami soal sehingga siswa tidak dapat menuliskan representasi simbolik matematika dari soal cerita yang diberikan seperti siswa tidak dapat menentukan atau tidak tahu operasi yang tepat yang dapat digunakan untuk menyelesaikan soal. (3) Kesalahan keterampilan proses. Kesalahan ini dilakukan oleh S1, S2, S3, dan S4. Penyebab siswa melakukan kesalahan ini karena siswa tidak mampu menyelesaikan soal yang diberikan dengan prosedur penyelesaian matematika yang benar seperti kesalahan urutan operasi hitung, salah melakukan perhitungan dan menentukan hasil perhitungan yang disebabkan karena siswa tidak teliti dalam melakukan proses perhitungan. (4) Kesalahan penulisan jawaban. Kesalahan ini dilakukan oleh S1, S2, S3, dan S4. Penyebab terjadinya kesalahan ini karena hampir sebagian siswa melakukan kesalahan pada pemahaman dan transformasi soal sehingga hasil akhir dari pekerjaan siswa jugapun menjadi salah. Selain itu, kesalahan ini juga dapat disebabkan karena adanya kesalahan pada proses perhitungan. Lebih lanjut, kesalahan dalam memahami dan mentransformasi masalah merupakan jenis kesalahan yang paling dominan dilakukan siswa.

Berdasarkan hasil penelitian maka disarankan kepada guru maupun calon guru untuk memfasilitasi dan mendampingi siswa-siswa yang melakukan kesalahan dalam mengerjakan soal cerita dan siswa yang memiliki kemampuan kognitif rendah agar dapat menghindari kesalahan yang dilakukan siswa pada saat mengerjakan soal cerita dan kepada siswa hendaknya lebih banyak berlatih secara mandiri mengerjakan soal terutama soal cerita. Selain itu, guru juga dapat mengintegrasikan soal cerita dalam pelaksanaan pembelajaran matematika, sebagai upaya untuk membiasakan siswa dengan soal-soal cerita. Adapun bagi siswa diharapkan agar dapat membiasakan diri untuk menuliskan informasi secara lengkap terlebih dahulu sebelum mengerjakan soal. Hal ini dimaksudkan untuk melatih siswa memahami masalah secara lengkap, teratur, sistematis, dan terutama melatih siswa menggunakan prosedur yang benar. Hal yang sama pun dapat dilakukan siswa selama mengerjakan atau melakukan proses perhitungan dengan adanya pendampingan dari guru. 


\section{Daftar Pustaka}

Abdullah, A. H., Abidin, N. L. Z., \& Ali, M. (2015). Analysis of students' errors in solving Higher Order Thinking Skills (HOTS) problems for the topic of fraction. Asian Social Science, 11(21), 133-142.

Ariestina SD, M. P., Yunarti, T., \& Sutiarso, S. (2014). Analisis Kesulitan Siswa Kelas VIII dalam Menyelesaikan Soal Cerita Matematika. Jurnal Pendidikan Matematika Unila, 2(2).

Bergeson, T. (2000). Using Research from the "Yesterday" Mind to "Tomorrow" Mind: Teaching and Learning Mathematics. Retrieved November 26, 2014

Dwidarti, U., Mampouw, H.L., Setyadi, D. (2019). Analisis Kesalahan Siswa Dalam Menyelesaikan Soal Cerita Pada Materi Himpunan. Journal Cendekia: Jurnal Pendidikan Matematika, 3(2), 315-322

Fuson, K. "Mathematics Education, Elementary". (1992) In M. Alkin (ed.) Encyclopedia of Educational Research (Sixth Ed. Vol. 3. New York: MacMillan.

Hartini, S., Suwarno dan Marsudi, S. 2008. Psikologi Pendidikan. Surakarta: Bimbingan dan Penyuluhan FKIP Universitas Muhammadiyah Surakarta.

Hasibuan, A. M., Saragih, S., \& Amry, Z. (2018). Development of Learning Materials Based on Realistic Mathematics Education to Improve Problem Solving Ability and Student Learning Independence.

Kristianto, E., Mardiyana, \& Saputro, D. R. S. (2019). Analysis of Students' Error in Proving Convergent Sequence using Newman Error Analysis Procedure. Journal of Physics: Conference Series, 1180(1).

Magrifah., Maidiyah, E., Suryawati. (2019). Analisis Kesalahan Siswa Dalam Menyelesaikan Soal Cerita Matematika Berdasarkan Prosedur Newman. Lentera Sriwijaya: Jurnal Ilmiah Pendidikan Matematika, 1 (2),1-12.

Mahmudah, W. (2018). Analisis Kesalahan Siswa dalam Menyelesaikan Soal Matematika Bertipe HOTS Berdasarkan Teori Newman. UJMC: Unisda Journal of Mathematics and Computer Science, 4(1), 49-56.

Peranginangin, S. A., Saragih, S., \& Siagian, P. (2019). Development of Learning Materials through PBL with Karo Culture Context to Improve Students' ProblemSolving Ability and Self-Efficacy. International Electronic Journal of Mathematics Education, 14(2), 265-274.

Peraturan Menteri Pendidikan Nasional Republik Indonesia. 2006. Peraturan Mentri Pendidikan Nasional Republik Indonesia Nomor 22 Tahun 2006 Tentang Standar Isi untuk Satuan Pendikan Dasar dan Menengah.

Roebyanto, G. \& S. H. (2017). Pemecahan Masalah Matematika Untuk PGSD. PT Remaja Rosdakarya.

Rohmah, M., \& Sutiarso, S. (2018). Analysis problem solving in mathematical using theory Newman. Eurasia Journal of Mathematics, Science and Technology Education, 14(2), 671-681.

Rostika, D., \& Junita, H. (2017). Peningkatan Kemampuan Pemecahan Masalah Siswa SD Dalam Pembelajaran Matematika Dengan Model Diskursus Multy Representation (DMR). EduHumaniora: Jurnal Pendidikan Dasar, 9(1), 35-46.

Sudirman, S., Cahyono, E., \& Kadir, K. (2019). Analisis Kemampuan Koneksi Matematis Siswa SMP Pesisir Ditinjau Dari Perbedaan Gender. Jurnal Pembelajaran Berpikir Matematika, 3(2).

Sukmadinata, Nana Syaodih. 2009. Metode Penelitian Pendidikan. Bandung: Remaja Rosdakarya.

Suyitno, A., \& Suyitno, H. (2015). Learning Therapy for Students in Mathematics Communication Correctly Based-on Application of Newman Procedure (a Case of Indonesian Student). International Journal of Education and Research, 3(1), 529-538.

White, A.L. (2010). Numeracy, Literacy and Newman's Error Analysis. Journal of Science an Mathematicis Education in Southeast Asia, 33(2), $129-148$. 